Chirurgia (2019) 114: 174-178

No. 2, March - April

Copyright@ Celsius

http://dx.doi.org/10.21614/chirurgia.114.2.174

\title{
Watch and Wait Strategy for Rectal Cancer: 15 Years After the First Published Study. Are We any Closer to the Non-operative Management of Rectal Cancer?
}

\author{
Adrian Tulin'1, Cornelia Nitipir², Iulian Slavu ${ }^{3}$, Vlad Braga ${ }^{3}$, Daniela Mihaila', Lucian Alecu' \\ 'General Surgery Clinic, Prof. Dr.”Agrippa Ionescu” Emergency Clinical Hospital, Bucharest, Romania \\ ${ }^{2}$ Emergency Clinical Hospital, Elias, Bucharest, Romania \\ ${ }^{3}$ General Surgery Clinic, Emergency Clinical Hospital "Floreasca”, Bucharest, Romania
}

Corresponding author:

Iulian Slavu, MD

General Surgery Clinic, Emergency

Clinical Hospital "Floreasca",

Bucharest, Romania

E-mail: iulian.slavu@yahoo.com

\section{Rezumat}

Strategia Watch and Wait pentru cancerul de rect: 15 ani de la primul studiu publicat. Suntem mai aproape de tratamentul non-operator al cancerului de rect?

Introducere: De-a lungul timpului, tratamentul cancerului rectal a evoluat semnificativ prin utilizarea sporită a radiochimoterapiei neoadjuvante.

Material şi metoda: Ghidul P.I.C.O.S a fost utilizat pentru a structura întrebările şi topica cercetării în vederea obținerii validitătii clinice. Rezultatele obținute au fost filtrate conform ghidului PRISMA.

Rezultate: Am identificat un număr de 42 de lucrări, după screeningul acestora, au rămas 27 pentru a completa cercetarea.

Discuții: Există un interes crescut față de managementul neoperator al cancerului rectal întrucât până la $25 \%$ dintre pacienții supuşi unui regim de radiochimioterapie preoperatorie au demonstrat răspuns patologic complet (absența celulelor tumorale pe specimenele rezecate). Aceste informatii conduc la ideea atrăgătoare că, în unele cazuri, intervenția chirurgicală poate fi evitată. Din nefericire, există o lipsă de date de calitate pentru a susține această nouă tendință. Datorită interesului recent crescut a fost creată o bază de date internațională în care pacienții aflați în perioada de w\&w pot fi înscrişi şi monitorizați. Până în prezent, baza de date conține peste 900 de pacienți. De asemenea, sunt în curs de finalizare studii prospective de calitate.

Concluzii: $\mathrm{Cu}$ toate aceste eforturi recente, utilizarea pe scară largă 
a acestei terapii este împiedicată de absența unei evaluări standardizate a acestor pacienți în timpul perioadei de urmărire.

Cuvinte cheie: tratament non-operator, cancer de rect, watch and wait

\begin{abstract}
Introduction: Over time, the management of rectal cancer has undoubtedly evolved with the use of neoadjuvant radiochemotherapy.

Material and method: The P.I.C.O.S guidelines were used to structure the questions and the research topic as to attain clinical validity. The results of the research were filtered in accordance with the PRISMA checklist.

Results: We identified 42 papers. After screening 27 papers were used to complete the analysis.

Discussion: There is an increased interest towards the non-operative management of rectal cancer, as up to $25 \%$ of patients with preoperative radiochemotherapy have demonstrated complete pathological response (absence of tumor cells on the operative specimens). This information leads to the tantalizing idea that in some cases, surgery can be avoided. Unfortunately, there is a lack of quality data to support this view. Due to increased interest in this subject, an international database in which patients with w\&w therapy can be enrolled and monitored. Up to now, the database contains over 900 patients. Also, quality prospective trials are emerging.

Conclusion: Even with all these recent efforts, the wide-use of this therapy is precluded due to the absence of a standardized evaluation of these patients in the follow-up period.
\end{abstract}

Key words: non-operative treatment, rectal cancer, watch and wait

\section{Introduction}

Colorectal cancer occupies at the moment the number three place in the world ranking of the most prevaling neoplasms (1). The treatment of colo-rectal cancer through adjuvant and neo-adjuvant therapies has evolved significantly over time (2). However, surgery remains the pillar of the treatment strategy (3). The standard treatment in stage II and III is surgical resection with total mesorectal excision (TME) and neoadjuvant radiotherapy/ chemotherapy (4). Of all the patients who undergo neoadjuvant therapy and surgery, up to $25 \%$ have a complete pathological response on the resected specimen (no tumor cells are identified at the histopathological examination) (4). The standard surgical interventions for rectal cancer are low anterior resection or abdominoperineal resection, both with TME. These interventions have important perioperative morbidity.
Up to $11 \%$ of these patients develop a fistula and up to $15 \%$ have a permanent stomy with an important decrease in the quality of life (5-7). Development of minimally invasive techniques such as laparoscopy does not seem to influence the rate of these complications (8).

Taking into account all these risks, solutions such as neoadjuvant therapy have been sought which may offer a complete clinical and pathological response (9). With the introduction of this new treatment strategy, other problems occur which refer to the definition of complete clinical response. In the case of resection, complete pathological response is defined as the absence of tumor cells on the examined specimen, but complete clinical response is inaccurately defined as it includes multiple criteria: the absence of rectal ulceration, absence of rectal stenosis, absence of a rectal mass at rectoscopy $(10,11)$. These two forms of assessment (pathologic response and clinical response) are not 
always consistent with each other (12). Complete clinical response was reported in up to $40 \%$ of the cases with neoadjuvant treatment $(13,14)$. After surgery, it was observed that half of these resected specimens contained tumor cells at histopathology examination $(13,14)$. Therefore the criteria of selection and safety of w\&w strategy raise serious question marks $(13,14)$.

In 2004 , an article was published by a group of Brazilian researchers who questioned decades of treatment and research in colorectal cancer, investigating comparatively two groups of patients (with and without surgery) who had complete clinical response after neoadjuvant treatment (15). Following the analysis of the results, they concluded that there were no differences in survival between the two groups of patients (15). A new treatment strateg had been defined - watch and wait (w\&w) or active surveillance as an alternative to surgery (16).

In the w\&w strategy, patients may refuse scheduled surgery after neoadjuvant radiotherapy. After long radiotherapy course (45-65 Gy), they will enter a surveillance program that includes regular MRI, rectoscopy and rectal examination. Although promising, these results have not been reproduced uniformly in randomized trials, so the safety of this procedure remains questionable.

The purpose of this review was to analyze the data published in the literature on this extremely attractive topic which gains momentum.

\section{Material and Method}

The research was performed using the PubMed database. The P.I.C.O.S concept (patient, intervention, comparator, outcome, study type) was used to structure the questions and the research topic as to attain clinical validity. The results of the search were filtered in accordance with the PRISMA checklist (Preferred Reporting Items for Reviews and Meta-Analysis). We used the standard recommendation of two independent readers who performed the selection and subsequent extraction process.

\section{Results}

We identified 42 papers from one medical database. After exclusion of 8 papers (duplicates), the number was reduced to 34 . Of these, 4 papers were not obtainable while other 3 papers were not appropiate for the research subject. 27 papers were used to complete the analysis.

\section{Discussion}

Historically, colorectal cancer has been associated with a rather poor prognosis, but with the standardization of its treatment, including neoadjuvant chemoradiotherapy and TME in surgery, there was a drastic reduction in the number of recurrences including in advanced tumors (17). The primary goal of neoadjuvant radiotherapy was to reduce tumor volume and increase the number of surgical procedures that save the anal sphincter. There are currently no clear criteria to guide a patient towards a w\&w strategy (18). Most studies published in the literature are of poor quality, retrospective with heterogeneous populations in terms of age, tumor staging and comorbidities. This lack of homogeneity in the analyzed populations results largely from the fact that the decision maker is ultimately the patient. Also, the experience of hospitals with this treatment strategy is limited. All of this translates into increased variability of the reported regrowth rates that is difficult to ignore. This variability ranges between 3.3\% and $33 \%$ (19).

The current trend of evidence-based medicine is defined as an approach to medical practice intended to optimize decision-making by emphasizing the use of evidence from welldesigned and well-conducted research obliges the clinician to pay increased attention to the design of the study so he can safely apply the results in his practice. Keeping this in mind, as of November 2018, there were no published prospective randomized trials on this subject (20).

There is however, one ongoing prospective trial, the results are due to be published this 
year. It compares subjects which have locally advanced rectal tumors who had complete clinical response after neoadjuvant chemoradiotherapy based on the w\&w strategy and patients with surgical intervention. The endpoint was the oncological outcome after a three-year interval (21). Data on this topic indicates that there is no difference in survival untill regrowth between w\&w patients with a complete clinical response and patients who undergo surgery after a 2-year follow-up interval $(22,23)$.

Up to $25 \%$ of patients who undergo neoadjuvant combined radiochemo-therapy have a complete pathological response (absence of tumor cells on the histopathology reports) $(24,25)$. Most of the recurrences occur in the first two years after completion of radiochemotherapy. Up to $30 \%$ of these patients will require a surgical intervention due to regrowth, and over $80 \%$ of them are surgically treated without a notable impact on survival compared to patients who had undergone surgery immediately after neoadjuvant therapy (26). Kong JC evaluated in a review published in 2017 the percentage of sphincter-saving procedures of the patients with regrowth in the w\&w protocol. He noted that in $84 \%$ of these patients, sphincter salvage surgery could be performed without a difference in overall survival compared to patients undergoing surgery first (27).

The proportion of patients with initially unresectable tumors at diagnosis who underwent surgery after the w\&w protocol is not known. There is currently no standard follow-up protocol, each clinic has its own surveillance programme. Steps towards standardization are being made. An International database for patients under the w\&w protocol has been set up to track the evolution of a large population from multiple centers all over the globe, in an attempt to deliver clinically applicable results. This database currently contains approximately 900 patients with rectal tumors who had a complete clinical response to neoadjuvant therapy. The problem with this database is that it does not contain the second arm of patients with surgery to whom it can be compared (26).

The selection process for this therapy is difficult and non-standardised. It is important that these patients understand that up to $30 \%$ of them will have residual tumor tissue despite the apparent complete clinical response (26).

Currently, treatment guidelines in the United Kingdom, recommend this strategy to patients, as long as they are informed that it is still in the experimental stages (28). In the European Union, the European Oncology Association (ESMO) recommends the w\&w strategy for high-risk patients. Again, uncertainty exists regarding the definiton of such criteria as "high risk" as they are not clearly defined (29).

\section{Conclusion}

Non-operative management with complete clinical response after neoadjuvant chemoradiotherapy may represent an option for some selected cases of rectal cancer only after the patient is informed about the limitations of this therapy. Although the concept of w\&w therapy has seen an increase in supportive data, its widespread use is precluded due to the absence of high quality, high volume prospective studies which translate in a lack of standardization of the treatment strategy.

\section{Conflicts of interests}

The authors declare no conflicts of interest.

\section{Authors Contributions}

Conception and design: Iulian Slavu, Adrian Tulin, Lucian Alecu. Provision of study material or patients: Iulian Slavu, Braga Vlad, Mihaila Daniela. Collection and assembly of data: Iulian Slavu, Braga Vlad, Mihaila Daniela. Data analysis and interpretation: Iulian Slavu, Braga Vlad, Mihaila Daniela. Manuscript writing: Iulian Slavu, Braga Vlad, Mihaila Daniela. Final approval of manuscript: Alecu Lucian, Tulin Adrian. 


\section{Funding}

No funding was required for this study.

\section{Conflict of Interest}

The authors declare no conflicts of interests.

\section{References}

1. GLOBOCAN. factsheet. http://globocan.iarc.fr/Pages/fact_sheets_ population.aspx.

2. Aly EH. Time for a renewed strategy in the management of rectal cancer: critical reflection on the surgical management of rectal cancer over 100 years. Dis Colon Rectum. 2014;57(3):399-402.

3. Nelson H, Petrelli N, Carlin A, Couture J, Fleshman J, Guillem J et al National Cancer Institute Expert Panel. Guidelines 2000 for Colon and Rectal Cancer Surgery. JNCI J Natl Cancer Inst. 2001;93(8):583-596.

4. Tural D, Selcukbiricik F, Özturk MA, Yildiz O, Turna H, Erdamar S, et al The relation between pathological complete response and clinical outcome in patients with rectal cancer. Hepatogastroenterology. 2013; 60(126):1365-70.

5. Alves A, Panis Y, Mathieu P, Kwiatkowski F, Slim K, Mantion G. Mortality and morbidity after surgery of mid and low rectal cancer: results of a French prospective multicentric study. Clin Res Hepatol Gastroenterol Clin Biol. 2005:29(5):509-14

6. Lange MM, Maas CP, Marijnen CA, Wiggers T, Rutten HJ, Kranenbarg EK, et al. Urinary dysfunction after rectal cancer treatment is mainly caused by surgery. Br J Surg. 2008;95(8):1020-8.

7. Smith FM, Waldron D, Winter DC. Rectum-conserving surgery in the era of chemoradiotherapy. Br J Surg. 2010;97(12):1752-64.

8. Shearer R, Gale M, Aly OE, Aly EH. Have early postoperative complications from laparoscopic rectal cancer surgery improved over the past 20 years? Colorectal Dis Off J Assoc Coloproctol G B Irel. 2013; 15(10):1211-26.

9. Perez R0. Complete clinical response in rectal cancer: a turning tide. The Lancet. Oncology. 2016;17(2):125-6.

10. Smith FM, Wiland H, Mace A, Pai RK, Kalady MF. Clinical criteria underestimate complete pathological response in rectal cancer treated with neoadjuvant chemoradiotherapy. Dis Colon Rectum. 2014;57(3): 311-5.

11. Hiotis SP, Weber SM, Cohen AM, Minsky BD, Paty PB, Guillem JG, et al. Assessing the predictive value of clinical complete response to neoadjuvant therapy for rectal cancer: an analysis of 488 patients. J Am Coll Surg. 2002;194(2):131-5; discussion 135-6.

12. Lai CL, Lai MJ, Wu CC, Jao SW, Hsiao CW. Rectal cancer with complete clinical response after neoadjuvant chemoradiotherapy, surgery, or "watch and wait". Int J Colorectal Dis 2016; 31:413-19.

13. Glynne-Jones R, Wallace M, Livingstone Jl, Meyrick-Thomas J. Complete clinical response after preoperative chemoradiation in rectal cancer: is a "wait and see" policy justified? Diseases of the colon and rectum. 1 2008;51(1):10-19; discussion 19-20.

14. Glynne-Jones R, Hughes R. Complete Response after Chemoradiotherapy in Rectal Cancer (Watch-and-Wait): Have we Cracked the Code? Clinical oncology. 2 2016;28(2):152-160.

15. Habr-Gama A, Perez RO, NadalinW, Sabbaga J, Ribeiro U, Silva e Sousa AH et al (2004) Operative versus nonoperative treatment for stage 0 distal rectal cancer following chemoradiation therapy: longterm results. Ann Surg 240(4):711-717 discussion 717-718.

16. Creavin B, Ryan E, Martin ST, Hanly A, O'Connell PR, Sheahan K et al. Organ preservation with local excision or active surveillance following chemoradiotherapy for rectal cancer. Br J Cancer. 2017; 116(2): 169-174.

17. Sebag-Montefiore D, Stephens RJ, Steele R, Monson J, Grieve R, Khanna S, et al. Preoperative radiotherapy versus selective postoperative chemoradiotherapy in patients with rectal cancer (MRC CR07 and NCIC-CTG C016): a multicentre, randomised trial. Lancet. 2009; 373(9666):811-20

18. Tarik Sammou, Brandee A. Price, Kate J Krause, and George J Chang, * Non-operative management or "watch and wait" for rectal cancer with complete clinical response after neoadjuvant chemoradiotherapy - a critical appraisal. Ann Surg Oncol. 2017;24(7):1904-1915.

19. Dossa F, Chesney TR, Acuna SA, Baxter NN. A watch-and-wait approach for locally advanced rectal cancer after a clinical complete response following neoadjuvant chemoradiation: a systematic review and meta-analysis. Lancet Gastroenterol Hepatol 2017;2:501-13.

20. Smith FM, Cresswell K, Myint AS, Renehan AG. Is "watch-and-wait" after chemoradiotherapy safe in patients with rectal cancer? BMJ 2018; 363:k4472 doi: 10.1136/bmj.k4472.

21. Observation versus surgical resection in patients with rectal cancer who achieved complete clinical response after neoadjuvant chemoradiotherapy. NCT02052921. https:// clinicaltrials.gov/ct2/show/record/ NCT02052921?term=non+operative+management\& cond=Rectal + Cancer\&rank $=4$

22. Sun Myint A, Smith FM, Gollins S, Wong H, Rao C, Whitmarsh K, et al. Dose escalation using contact $\mathrm{X}$-ray brachytherapy after external beam radiotherapy as nonsurgical treatment option for rectal cancer: outcomes from a single-center experience. Int $\mathrm{J}$ Radiat Oncol Biol Phys. 2018;100(3):565-573.

23. Chadi SA, Malcomson L, Ensor J, Riley RD, Vaccaro CA, Rossi GL, et al. Factor influencing local regrowth after watch-and-wait for clinical complete response following chemoradiotherapy in rectalcancer: an individual participant data meta-analysis (InterCoRe consortium). Lancet Gastroenterol Hepatol. 2018;3(12):825-836.

24. Smith FM, Waldron D, Winter DC. Rectum-conserving surgery in the era of chemoradiotherapy. Br J Surg 2010;97:1752-64.

25. Smith FM, Wiland H, Mace A, Pai RK, Kalady MF. Clinical criteria underestimate complete pathological response in rectal cancer treated with neoadjuvant chemoradiotherapy. Dis Colon Rectum 2014;57:311-5.

26. van der Valk MJM, Hilling DE, Bastiaannet $E$, Meershoek-Klein Kranenbarg E, Beets GL, Figueiredo NL, et al. Long-term outcomes of clinical complete responders after neo-adjuvant treatment for rectal cancer in the International Watch \& Wait Database (IWWD): an international multicentre registry study. Lancet. 2018; 391(10139):2537-2545

27. Kong JC, Guerra GR, Warrier SK, Ramsay RG, Heriot AG. Outcome and salvage surgery following "watch and wait" for rectal cancer after neoadjuvant therapy: a systematic review. Dis Colon Rectum 2017; 60:335-45.28177997

28. Gollins S, Moran B, Adams R, Cunningham C, Bach S, Myint AS, et al. Association of Coloproctology of Great Britain \& Ireland (ACPGBI): guidelines for the management of cancer of the colon, rectum and anus (2017) - multidisciplinary management. Colorectal Dis. 2017;19 Suppl 1:37-66.

29. Glynne-Jones R, Wyrwicz L, Tiret E, Brown G, Rödel C, Cervantes A, et al. ESMO Guidelines Committee. Rectal cancer: ESMO Clinical Practice Guidelines for diagnosis, treatment and follow-up. Ann Oncol. 2018;29(Supplement_4):iv263. 